\title{
THE ROLE OF ULAMA AND MUSLIMS IN STRENGTHENING NATIONAL UNION OF THE REPUBLIC OF INDONESIA (The Government of the Republic of Indonesia)
}

\author{
Taufiqurokhman \\ Faculty of Social and Political Science \\ Universitas Prof.Dr. Moestopo (Religious) \\ email: taufiqurokhman1971@gmail.com
}

\begin{abstract}
The Indonesian government with the central position of power in Java and the form of the Government of the Unitary State of the Republic of Indonesia (NKRI), the spread of Islam in the Land of Java in the framework of NKRI Government implemented by the scholars of Indonesia especially the spread of Islam carried out widely with the appearance of Wali Songo in Java. The presence of the scholars by giving his dakwah to the wider community, and the state of Indonesia is the largest adherents of Islam. At the end of 2014 came the figure of President Jokowi is quite phenomenal and assume the role of President Jokowi many do the ways of Islamic da'wah as did the scholars and guardians songo. Namely break through the customs of feudalism culture, like done by the scholars and guardian songo who plunge into the community perform da'wah. Judging from the track record of the political journey Jokowi Government which he lived with blusukan leadership model, which is closer to the small community, has led Jokowi in the highest seat of leadership, namely the president of the VII of the Republic of Indonesia. Therefore, this scientific paper, will explore and analyze the role of ulama in strengthening the government of the Republic of Indonesia, which is commanded by President Jokowi, the president of Indonesia to VII, So that can be seen how far the alignment of scholars and Muslims in Indonesia. Questions in the formulation of the problem in this writing is the role of scholars and Muslims in the Government of NKRI. Type of research used to answer these questions is the type of library research (library research), with the nature of descriptive analytic research with socio-political approach. Data obtained from journal books, laws, documentation, research reports and other sources relevant to the studied discussion. After all the data collected, then the next step is to analyze the data with explorative deductive analysis, that is how the political behavior of President Joko Widodo in his role against Muslims led by the scholars in Indonesia. After conducting a study of the data, this study drew the conclusion of a leader's social behavior affecting the government of his dreams. As in the case studied in this study, it was found that the role of scholars and Muslims has a strong influence to strengthen the government of the Unitary Republic of Indonesia.
\end{abstract}

Keywords: Role of Ulama and Moslem, Strengthening, Government of NKRI. 


\section{INTRODUCTION}

The name of the Great Ulama ${ }^{1}$ who brought Islamic reformation in Indonesia in the late 1800 s and early 1900 AD not only studied in Indonesia alone, but they studied for years in Mecca. It is recorded in history that the scholars of the reformer were also studying to one of the teachers, who was also a man who came from Indonesia and was the Imam of the Grand Mosque at that time. As is known all along, the process of Islamic development in Indonesia passes through various epochs, including the times of the rosul and companions, the dynasty of the Abbasid dynasty, the era of the Uma'iyah dynasty, the time of Kemal At-Tattur in Turkey, and during the old Order. And the most influential and known in the island of Java is the history of Islamic civilization in the walisongo. History of Islamic journey with the existing leadership model in Islam, then the entire Indonesian Ulama agreed through the figures or founthing father by forming the government of the Republic of Indonesia which currently Pancasila became the basis of the State.

Walisongo journey has an important role in the process of Islamic civilization in Java. Where the land of Java is the land of the

1 The great cleric is Shaykh Ahmad Khatib AlMinangkabawi. So the journey of the scholars towards the spread of Islam in Indonesia coloring the current Indonesian government, which takes the form of Government of the Unitary State of the Republic of Indonesia (NKRI) central government of Indonesia with the capital of DKI Jakarta today. So also the cultures of Hindu Buddhism and Christianity have long been successfully adapted and interpreted into the culture of Islam in the homeland of Indonesia which is done through the da'wah of ulama and guardian songo in the land of Java. Of course, the da'wah done by the wali songo do not deviate from the teachings of Islam itself. And that certainly can be entertainment for the people of Indonesia, even up to now still often we hear songs from figures walisongo. This is the basic culture that has been done by the wali songo at the time, so that the current culture of Indonesia stands firmly on the basis of his country Pancasila.

\section{RELIGION IN UNIVERSAL PERSPECTIVE}

Speaking of recognized religions in Indonesia, namely Islam, Christianity, Buddhism and Hinduism as well as the flow of belief, the concept of religion in a universal perspective, then the word piety should also apply to other religions. The Indonesian context of the word piety has in fact been accepted as a national idiom. And has become part of the doctrine of KORPRI $^{2}$ and $\mathrm{TNI}^{3}$. Thus, the problems that arise from every adherent of religion in Indonesia word piety above that has been

\footnotetext{
${ }^{2}$ That is the doctrine of Panca Prasetya from KORPRI (Korp Pegawai Republik Indonesia)

3 That is the doctrine of Sapta Marga from TNI (Indonesian National Army)
} 
translated lies in the interpretation of each adherents or adherents. So that the role of scholars and Muslims in the government of NKRI in Indonesia actually strengthen the Government of President Joko Widodo with the form of the Unitary State of the Republic of Indonesia (NKRI).

Mathematician

and philosopher Purworejo, Ikhsan Haryono (2015), said that piety is supposed to be applicable to religions other than Islam. If piety has an implementation meaning for a real life. Ikhsan translates the word piety as an attitude and action that obeys sunnatullah. Thus, the word piety is closely related to the notion of obedience or human attachment to the laws of nature. Ikhsan then gives an example to a fruit seller who manipulates the scales, even though his religion is one in Indonesia, is not a cautious person. Conversely, a fruit seller who weighs properly, though Buddhist, Christian or Muslim, is a cautious person. Manipulating the scales, at a glance the problem looks trivial. However, if viewed from a cosmological perspective, manipulating the scale is the act of "deviation of religious values" against sunnatullah, namely mendestruksi law of gravity. As is known, the weight of an object on earth depends on the force of gravity somewhere. Therefore, if one manipulates the scales, the same does not recognize the law of gravity. The man who manipulates the scales means to have tried to distort the natural law, or sunnatullah.

In other words, a person who manipulates the scales means "noncautious". And Allah SWT is angry with such a person. Such pious interpretation is clearly more applicable. Not related to a particular religion. Any religious person if his actions follow sunnatullah, then including the cautious. On the other hand, even if the religion is Christian, but if the actualization of Religious Values in Strengthening NKRI his actions do not follow sunnatullah, then including people not cautious. So the consequence of this approach is very broad, depending on who uses it. For example, Muslims who destroy the forest include not cautious. Because the existence of forests is a "natural inevitability" to conserve and conserve natural resources.

In other cases, it can be seen the story of entering the paradise of a prostitute rather than a murderer and a robber who never wished to repent to Allah Almighty. Where a prostitute can give a drink to a thirsty animal in the middle of the desert then a prostitute is sucking his behavior by repenting to Allah swt for obtaining guidance from Allah swt. From this approach, Allah Almighty may very much like the repented prostitute then he is conscious of doing the behavior by giving a drink to the thirsty dog. The word piety is deliberately described in this writing because of the 
approach of "the role of scholars and Muslims in the strengthening of NKRI government" where the Indonesian society is very very pluralist.

This writing also explains the religious teachings that exist in Indonesia ${ }^{4}$. Of course, of the six religions, Islam is the most dominant in the narrative of the establishment and strengthening the Republic of Indonesia in the current government. Because Islam is the majority religion of Indonesia. And the word piety in Islam is the "key" in the role of scholars and Muslims in strengthening the Unitary State of the Republic of Indonesia. In discussing the faith, so the understanding of piety in Islam should be compatible also with the "core teachings" of those religions. With the above approach, if the word piety can be applied to other religions without any problem of sacred narrative, then every religion in Indonesia basically has the same purpose: invites people to pursue the truth in life according to the sunnatullahnya contained in the government of NKRI there is this moment.

From this perspective, Muslims in understanding the verses of the Qur'an (Al-Baqarah 62) The verse indicates that truth is universal. Therefore, if truth is the basis of piety, then the meaning of piety is universal. From this perspective, then

\footnotetext{
${ }^{4}$ Namely Islam, Christianity, Catholicism, Hinduism, Buddhism and Confucianism, which is associated with support for the NKRI government
}

religious pluralism is a necessity. Indonesia as a pluralist country with its diverse cultures called Bhineka Satu Ika. Where the population embraces various religions, should not have to worry that these religions disrupt the integrity of NKRI. Again, it needs to be underlined, pluralism and multiculturalism is a necessity. A person becomes Christian or Buddhist, Muslim, or Hindu, and others are closely related to his socio-cultural conditions. So that the mastery of religious values in Strengthening NKRI someone is destined to be born from a family or nation that embraces Islam, Christianity, Buddhism, the flow of belief, then the possibility is very small to get out of that background. Since religion is something given, tolerance and multiculturalism are inevitable.

Yet in its development, it is often the case that some religious followers tend to form an exclusive religious worldview as opposed to the spirit of pluralism and multiculturalism. This happens because religion is often better understood as a sacred and absolute area. Not dipamahi in a broader frame, especially the government of the Republic of Indonesia has given free space to each of its adherents to embrace religion and belief. Even when religion is involved in even worldly affairs, it is still understood as the sacred and absolute sacrifice of sacred duties. Because of the value of a sacred, religious and 
cultural contact often creates tension. Such conditions have occurred in various regions that became centers of interreligious meetings such as in the Middle East, North Africa, Western Europe, and others. War between Christians (Catholics and Protestants), then between Islam and Christianity (the Crusade) became a black record of the history of religious life.

Later, the emergence of ISIS (Islamic State of Iraq and Syria), which established the country of horror and terror in the Middle East, and can be handled its spread in Indonesia and even crushed several times in Indonesia at the time teroro bomb that occurred in Sarinah Jakarta recently, trauma among mankind. ISIS on behalf of Islam has spread terror to different people and different religions. So the world again realized that religion is a potential conflict that can threaten humanity.

With the background of the latest events such as ISIS terror is, the role of scholars and Muslims of Indonesia again rearranged the line by continuing to massively perform da'wah in the followers of Islam to Islam Islam should not be suspected as the religion of the originator of terror. In this connection, this paper appreciates research on the role of scholars and Muslims in the Government of NKRI.

The purpose of this paper is to know about the history of early scholars in Indonesia and can find out how civilization is peaceful in Indonesia especially in Java land during the walisongo and to how far the role of scholars and Muslims in the government of the Unitary Republic of Indonesia (NKRI).

The expected benefit is this writing, is expected to add insight for writers and readers and can provide and increase knowledge about some matters concerning "the role of Islamic scholars and uamat in the government of NKRI".

From this perspective, Muslims in understanding the verses of the Qur'an ${ }^{5}$ (Al-Baqarah 62) The verse indicates that truth is universal. Therefore, if truth is the basis of piety, then the meaning of piety is universal. From this perspective, then religious pluralism is a necessity. Indonesia as a pluralist country with its diverse cultures called Bhineka Satu Ika. Where the population embraces various religions, should not have to worry that these religions disrupt the integrity of NKRI. Again, it needs to be underlined, pluralism and multiculturalism is a necessity. A person becomes Christian or Buddhist, Muslim, or Hindu, and others are closely related to his socio-cultural conditions. So that the mastery of religious values in Strengthening NKRI someone is

\footnotetext{
5 "Sesungguhnya orang-orang mukmin, orang-orang Yahudi, dan orang-orang Nasrani dan orang-orang Shabiin, siapa saja diantara mereka yang benar-benar beriman kepada Allah, hari Kemudian dan beramal saleh, mereka akan menerima pahala dari Tuhan YME mereka, tidak ada kekhawatiran kepada mereka, dan tidak (pula) mereka bersedih hati."
} 
destined to be born from a family or nation that embraces Islam, Christianity, Buddhism, the flow of belief, then the possibility is very small to get out of that background. Since religion is something given, tolerance and multiculturalism are inevitable.

Yet in its development, it is often the case that some religious followers tend to form an exclusive religious worldview as opposed to the spirit of pluralism and multiculturalism. This happens because religion is often better understood as a sacred and absolute area. Not dipamahi in a broader frame, especially the government of the Republic of Indonesia has given free space to each of its adherents to embrace religion and belief. Even when religion is involved in even worldly affairs, it is still understood as the sacred and absolute sacrifice of sacred duties. Because of the value of a sacred, religious and cultural contact often creates tension. Such conditions have occurred in various regions that became centers of interreligious meetings such as in the Middle East, North Africa, Western Europe, and others. War between Christians (Catholics and Protestants), then between Islam and Christianity (the Crusade) became a black record of the history of religious life.

Later, the emergence of ISIS (Islamic State of Iraq and Syria), which established the country of horror and terror in the Middle East, and can be handled its spread in Indonesia and even crushed several times in Indonesia at the time teroro bomb that occurred in Sarinah Jakarta recently, trauma among mankind. ISIS on behalf of Islam has spread terror to different people and different religions. So the world again realized that religion is a potential conflict that can threaten humanity.

With the background of the latest events such as ISIS terror is, the role of scholars and Muslims of Indonesia again rearranged the line by continuing to massively perform da'wah in the followers of Islam to Islam Islam should not be suspected as the religion of the originator of terror. In this connection, this paper appreciates research on the role of scholars and Muslims in the Government of NKRI.

The purpose of this paper is to know about the history of early scholars in Indonesia and can find out how civilization is peaceful in Indonesia especially in Java land during the walisongo and to how far the role of scholars and Muslims in the government of the Unitary Republic of Indonesia (NKRI).

The expected benefit is this writing, is expected to add insight for writers and readers and can provide and increase knowledge about some matters concerning "the role of Islamic scholars and uamat in the government of NKRI". 


\section{ISLAMIC MASS \\ ORGANIZATIONS \\ STRENGTHEN THE NKRI GOVERNMENT}

The three largest Islamic organizations in Indonesia ${ }^{6}$, such as the Persatuan Islam (Persis) known as the puritan movement, as well as the Ikatan Jamaah Ahulul Bait Indonesia (IJABI), which is a Shia representation and therefore a part of the trans national movement; Making the NKRI as a joint political building that in strengthening and strengthening the existence of NKRI.

IJABI in the Declaration of Unity November 14, 2013 positioned itself as a nation child born in Indonesia and made Pancasila as the principle of statehood. Persis and Matla'ul Anwar (MA) also placed the NKRI as the final building of the state, by placing Pancasila as a philosophy and Islam as an aqidah. Indeed, in this study, the Islamic groups studied are Persis, Matla'ul Anwar (MA) and IJABI, as representations of modernist, traditionalist and Shiite groups. The election of these three groups is based on the need to cover moderate views of Islam from minority groups, since the views of moderate Muslim majority such as Nahdlatul Ulama (NU) and Muhammadiyah, are widely known. The selection of these three groups is also underpinned by a desire to prove that although among

${ }^{6}$ namely Persis, Ikatan Jamaah Ahlul Bait Indonesia (IJABI) and Mathlaul Anwar are the three major Islamic organizations that strengthen the government of NKRI. the Muslim minority, nationalism still gets its place.The three largest Islamic organizations in Indonesia, such as the Persatuan Islam (Persis) known as the puritan movement, as well as the Ikatan Jamaah Ahulul Bait Indonesia (IJABI), which is a Shia representation and therefore a part of the trans national movement; Making the NKRI as a joint political building that in strengthening and strengthening the existence of NKRI.

$\mathrm{IJABI}^{7}$ in the Declaration of Unity November 14, 2013 positioned itself as a nation child born in Indonesia and made Pancasila as the principle of statehood. Persis and Matla'ul Anwar (MA) also placed the NKRI as the final building of the state, by placing Pancasila as a philosophy and Islam as an aqidah. Indeed, in this study, the Islamic groups studied are Persis, Matla'ul Anwar (MA) and IJABI, as representations of modernist, traditionalist and Shiite groups. The

\footnotetext{
${ }^{7}$ Pada tanggal 1 Juli 2000 di Gedung Merdeka Bandung dideklarasikanlah berdirinya organisasi massa Ikatan Jamaah AhlulBait Indonesi. Ormas ini dipelopori oleh tokoh intelektual Indonesia Dr. Jaluluddin Rakhmat, M.Sc yang kini duduk sebagai ketua Dewan Syuro'. Kang Jalal (akrab disebut demikian) yang pakar komunikasi ini juga dikenal sebagai cendikiawan muslim Indonesia. Kang Jalal mendirikan bersama beberapa orang diantaranya dua orang doktor dari ITB yaitu Dimitri Mahayana dan Hadi Suwastio Pendirian IJABI tersebut tentunya didasarkan pada perkembangan yang digambarkan di atas. IJABI terdaftar secara resmi di Departemen Dalam Negeri melalui Direktorat Jendral Kesatuan Bangsa dan Perlindungan Masyarakat nomor : 127 Tahun 2000/D.I tanggal 11 Agustus 2000. Pendirian dan pengembangan IJABI ini memang banyak dipelopori oleh para pencinta ahlulbait dari kalangan Syi'ah (imamiyah) tetapi misi IJABI adalah menghimpun seluruh pencinta ahlulbait dari kalangan manapun untuk melakukan kerja-kerja pemberdayaan mustadha'afin dan pencerahan pemikiran umat, yang tampaknya dengan ormas yang ada sekarang akan sulit efektif karena banyaknya kontaminasi politik yang bias konflik politik.
} 
election of these three groups is based on the need to cover moderate views of Islam from minority groups, since the views of moderate Muslim majority such as Nahdlatul Ulama (NU) and Muhammadiyah, are widely known. The selection of these three groups is also underpinned by a desire to prove that although among the Muslim minority, nationalism still gets its place.

Second, for Christians, religion and nationalism are not contradictory. It is based on the Two Laws of Love, namely love of God and fellow human beings. That is, loving human beings do not recognize territorial boundaries. So every Christian must uphold humanity in all nationalities. In the context of $\mathrm{NKRI}^{8}$, Christians apply the kingship of God, not the kingdom of God. For the latter, the kingdom of God must be in the form of an institution with clear territory. As for kingship of God, the kingdom of God is manifested through the application of the social values of Christ, not the institution of the Christian state.

Thus, Christians can still realize the kingship of God through

\footnotetext{
${ }^{8} \mathrm{NKRI}$ is a form of state that consists of a wide and scattered area with various customs, tribes, beliefs and cultures that have the basic goal of becoming an independent nation, united, sovereign, just and prosperous. The term of the Unitary State of the Republic of Indonesia demands the 1945 Constitution Article 1 (1) reads as follows: The State of Indonesia is the Unitary State, which is a Republic. This provision is described in Article 18 of the 1945 Constitution (1) which states that the Unitary State of the Republic of Indonesia is divided into provinces and provinces divided into cities and districts, where each city, district and province have local government regulated By law.
}

the form of state of NKRI. So that the existence of religious values will in fact Reinforce NKRI. Third, for Catholics, the relationship of religion and nationalism is represented by the term Invocatio Dei, inviting God in the life of a country. The meaning of this term is religion is an essential part of the state, so one of the tasks of the state lies in the guarantee of religious rights. This is reinforced by the slogan of the Indonesian independence struggle figure from Catholicism, namely Monsignor Soegijapranata, "100\% Catholic, 100\% Indonesia".

That is, faith and nationality are not opisisi. Quite the contrary: nationality is the real manifestation of faith. This is based on the secular assumption that Jesus established, "Give Caesar what is rightfully grant him what is his due (Matthew 22:21), that is, the territory of the state is different from that of the divinity so that obedience to the government does not reduce obedience Against the God Fourth, for the Hindu, nationalism is familiar in its history Seloka Bhinneka Tunggal Ika which is the motto of unity in difference, taken from the philosophy of life during the longing of the Majapahit Kingdom.Seloka, quoted from the Book of Sutasoma of the work of $\mathrm{Mpu}$ Tantular illustrates the essence of truth One because there is no ambiguous truth (tanhana dharma mangwra).

Thus, Indonesian nationality is rooted in the history and culture of 
the Nusantara community where Hinduism teachings are one of the foundations of a strong view of life. Therefore, Hindus feel to be part of RI nationality historicity, so still defend the unity of NKRI. Fifth, for Buddhists, the nationalist doctrine found in the Book of Sigalovada Sutta is the book xx Actualization of Religious Values in Strengthening the Unitary State of the Republic of Indonesia. In it, nationalism is based on a simple principle: "Do not let evil happen in your kingdom". That is, wherever Buddhists are, they must uphold the truth. Thus, nationalism is understood in two ways. First, the enforcement of the truth so that the most important is not the pattern of nationality, but the ability to uphold the Dharma in the national territory.

Second, love to fellow beings as a community service in the framework of life of the nation. Sixth, while for the Confucian people, the importance of nationalism lies in the loyalty of the people to the state, when the state is able to prosper the people. As described in the Book of Lun Yu, the government is based on virtues like the north pole that remains in place, while the stars revolve around it. The State is guided by the Law, in order to keep the people from dropping their self-esteem for injuring their human dignity. Thus, nationalism manifests in the role of the state to realize the noble values that exist within the rule of law and its founding philosophy.

\section{THE ROLE OF WALI SONGO FOR MUSLIMS IN JAVA LAND}

\section{Sheikh Maulana Malik Ibrahim} (sunan gresik):

Maulana Malik Ibrahim or Makdum Ibrahim As-Samarkandy is thought to have been born in Samarkand, Central Asia, in the first half of the 14th century. The Meehmanic Land of Jawi version called Asmarakandy, following the pronunciation of the Javanese tongue against As-Samarkandy, turned into Asmarakandi. Maulana Malik Ibrahim is sometimes also called the Sheikh Maghribi. Some people also call it Grandfather Pillow. He is related to Maulana Ishaq, a famous cleric in Pasai Ocean, and father of Sunan Giri (Raden Paku). Ibrahim and Ishaq were the sons of a Persian cleric, named Maulana Jumadil Kubro, a great scholar of Ahlussunnah with the Shafi'i who settled in Samarkand. Maulana Jumadil Kubro is believed to be the tenth seed of Sayyidina Hussein, the grandson of the Prophet Muhammad (peace and blessings of Allaah be upon him). Maulana Malik Ibrahim had lived

\footnotetext{
${ }^{9}$ Walisongo or Walisanga is known as the spreader of Islam in the land of Java in the 14th century. They live in three important areas of the north coast of Java Island, namely Surabaya-Gresik-Lamongan-Tuban in East Java, Demak-Kudus-Muria in Central Java, and Cirebon in West java. Walisongo era is the end of the era of Hindu-Buddhist dominance in the archipelago culture to be replaced with Islamic culture. They are symbols of the spread of Islam in Indonesia, especially in Java. Of course, many other figures also play a role. Yet their enormous role in establishing the Islamic Kingdom in Java, as well as its influence on the wider culture and the da'wah directly, made these Walisongos more widely spoken than others.
} 
in Campa, Thailand, and then Cambodia for 13 years since 1379.

He married the daughter of Campa king named Dewi Candrawulan, who gave her two sons, Raden Ali Rahmatullah (Sunan Ampel) and Sayyid Ali Murtadha alias Raden Santri. In 1392 Maulana Malik Ibrahim moved to Java. In da'wah, Maulana Malik Ibrahim uses wise and appropriate strategies based on the teachings of the Qur'an: "Call (humankind) into the path of your Lord with wisdom and good teaching, and debate with them in a good way." An Nahl: 125). In Java, Sheikh Maulana Malik Ibrahim is not only dealing with Hindu society, but also has to be patient with non-believers as well as those who follow the heresy, as well as to straighten the faith of the Muslims mixed with polytheistic activities. On the basis of this Islam, the teachings of Sheikh Maulana Malik Ibrahim grew rapidly in the Java land community as adherents of the largest Islamic teachings in Indonesia. Even in the existing literature, Sheikh Maulana Malik Ibrahim also teaches agriculture and medicine in Gersik land which is the end of the land community of jawaahli agriculture and medicine. His good personality attracted local people so they flocked to Islam voluntarily and became his faithful followers.

Sheikh Maulana Malik Ibrahim also invited King Brawijaya, king of Majapahit, to convert to Islam. But King Brawijaya insisted on maintaining the old religion. Sheikh Maulana Malik Ibrahim is a wali who is considered the father of the Wali Songo. After he built the pesantren, he died in Gresik in $822 \mathrm{H}$ or $\mathrm{M}$. His grave is now located in Kampung Gapura, Gresik, East Java.

\section{Sunan Ampel:}

Sunan Ampel named Raden Ali Rahmatullah is the eldest son of Maulana Malik Ibrahim. According to Babad Tanah Jawi and Sunan Kudus Lineage, in his childhood Sunan Ampel known as Raden Rahmat. He was born in Campa in 1401 AD The name Ampel himself, identified with the name of the place where he lived long. In the Ampel or Ampeldenta area, the area that is now part of Surabaya (Wonokromo City now). Sunan Ampel's teachings to date have great influence on the people of Java soil even spread throughout the corners of Indonesia through syiar Islamnya. His famous teachings are Moh Limo's philosophy or do not want to do five disgraceful things: (1) Moh Main or do not want to gamble; (2) Moh Ngombe or do not want to drink wine or get 
drunk; (3) Moh Maling or unwilling to steal; (4) Moh Madat or do not want to suck opium, marijuana, and others; (5) Moh Madon or do not want to commit adultery / play a woman who is not his wife.

Prabu Brawijaya is very pleased with Raden Rahmat's result. The king considers the religion of Islam is a noble character of noble character, so when Raden Rahmat then announced his teachings is the religion of Islam then King Brawijaya not become angry, only when he was invited to Islam, he did not want. He wants to be the last Hindu King in Majapahit. Raden Rahmat is allowed to broadcast Islam in the region of Surabaya and even throughout the Majapahit region, with the notion that the people should not be forced. From here the role of guardian songo and ulama put the foundation of the spread of Islam in the land of Java where Islam as a peaceful religion for the people of Indonesia.

Raden Rahmat also explained that there is no compulsion in religion. After Sheikh Maulana Malik Ibrahim died, then Sunan Ampel was appointed as elder Wali Songo, as mufti or Islamic religious leader of the Land of Java. Some of the students and sons of Sunan Ampel himself are also members of Wali Songo, they are Sunan Giri, Sunan
Bonang, Sunan Drajat, Sunan Kalijaga, Sunan Muria, Sunan City or Raden Patah, Sunan Kudus, and Sunan Gunungjati. Raden Patah or Sunan Kota was once a member of Wali Songo to replace the position of one of the wali who died. With the appointment of Sunan Ampel as an elder, the other guardians are subservient to his words. Including his fatwa in deciding war with the Majapahit. Sunan Ampel's attitude towards the old customs is very cautious, this is in accordance with the spread of Islam in Indonesia which adopts from the teachings of the specialist guardian songo supported by Sunan Giri and Sunan Drajad.

As it once was in the deliberations of the Guardians at Demak Great Mosque. At that time Sunan Kaljaga proposed that Javanese customs such as selamatan, bersaji, art of wayang and gamelan entered the sense of Islam. Sunan Kalijaga said Sunan Kalijaga asked Sunan Ampel, "Is it not worrying in the future that the old customs and ceremonies will be considered as teachings that come from Islam?

If it is left, it will be heresy. "In the consultation, Sunan Kudus answered Sunan Ampel's question," I agree with Sunan Kalijaga's opinion that old customs can still be directed to the religion of Tawheed then we will 
give him the color of Islam. While the old customs and beliefs that clearly lead to our idolatry live altogether. For example, gamelan and shadow puppets, we can give it the color of Islam according to the taste of society. As to the concerns of Kanjeng Sunan Ampel, I have confidence that in the future there will be one who perfected it. "The two seemingly contradictory opinions actually contain wisdom. The opinion of Sunan Kalijaga and Sunan Kudus is true that Islam is quickly accepted by Javanese, and this is proven, because the two Guardians are good at marrying old customs that can be tolerated by Islam, many Javanese people flock to Islam. In principle they are willing to accept Islam first and little by little they will be given understanding of the hygiene of tawhid in their faith. Here is the basis of the spread of Islamic teachings conducted by the wali songo so that until now still a strong foundation in the existing NKRI government today.

3. Sunan Giri (Sheikh Maulana Ishak): in the early 14th century CE,

Blambangan Kingdom was ruled by Prabu Menak Sembuyu, one of the descendants of King Hayam Wuruk of Majapahit Kingdom. The king and his people are Hindus and some are Buddhists. One day, Prabu Menak
Sembuyu was restless, as did his queen, the case of their only daughter having fallen ill for several months. It has been attempted to bring in physicians and healers to cure but the princess has not healed as well. Indeed at that time the Kingdom of Blambangan was hit by a creature or an outbreak of disease. Many have fallen victim. According to the description of the babad of Java, the next day the pain dies. The whole population was very concerned, mourning, and almost all the daily activities became totally stuck. On the advice of the empress, King Menak Sembuyu then held a contest, who can heal his daughter will be taken son-in-law and who can drive outbreaks of disease in Blambangan will be appointed as Regent or Raja Muda. The contest is spread across almost all corners of the country. A day, two days, a week, even months later no one expressed his ability to follow the contest. The consort grew more saddened by her heart. Praku Menak Sembuyu tried to console his wife by assigning Patih Bajul Sengara to find a magician to cure his daughter's illness. Patih Bajul Sengara finally met with Resi Kandabaya who know the existence of a powerful figure from the country across. The person in question is Sheikh Maulana Ishak who is preaching secretly in the country of 
Blambangan.Patih Bajul Sengara can meet with Sheikh Maulana Ishak who was talking in a cave. After negotiations that the king and people of Blambangan want to be invited to Islam then Sheikh Maulana Ishak willing to come to Blambangan palace. He is good at the field of science ketabiban, Princess Dewi Sekardadu healed after being treated. Pegebluk also disappeared from the Blambangan region. As per the promise of the king then Sheikh Maulana Ishak married with Dewi Sekardadu and given the position as Duke to control part of Blambangan region.

How to propagate Raden Paku; He preached in a way while sailing he broadcast Islam to the local population so that his name is quite famous in the archipelago. Over time the trade activity did not satisfy his heart. Raden Paku bertafakur in a quiet cave, only bermunajat to God in the village of Kembangan and Kebonmas. He founded pesantren in Sidomukti village, the pesantren was called Pesantren Giri. Giri in Sanskrit means mountain. The way of preaching of the guardians of this songo which then disebakan by the scholars in a peaceful way without coercion even to the point ii the scholars in Indonesia still continue to preach to spread to the people of Indonesia.

\section{Sunan Bonang:}

Sunan Bonang named original Sheikh Maulana Makdum Ibrahim, son of Sunan Ampel and Dewi Condrowati who often called Nyai Ageng Manila. Thus Raden Makdum is one of Prince Majapahit. As a teenager, Radem Makdum Ibrahin and Raden Paku continued Islamic studies in Pasai. They learn to Shaykh Awalul Islam or the real father of Sunan Giri or Raden Paku, Sheikh Maulana Ishak.

Method of propagation of Sunan Bonang; In dakwah, Raden Makdum Ibrahim is often using folk art to attract their sympathy, which is a set of gamelan called Bonang. Bonang is a kind of brass that is highlighted in the middle. When the lump was beaten with softwoods came a melodious voice in the ears of the local people. The songs taught by Raden Makdum Ibrahim are tembang which contains the teachings of Islam. So without the feeling the population has been studying Islam with pleasure, not by coercion. Students Raden Makdum Ibrahim is very much, both located in Tuban, Bawean Island, Jepara, Surabaya and Madura. Because he often uses bonang in da'wah then the community gave him the title of Sunan Bonang.

Literary works of Sunan Bonang; He also created literary works called suluk. Until now the 
literary work of Sunan Bonang is considered as a very great literary work, full of beauty and the meaning of religious life. The literary work of Sunan Bonang is still used today by the ulama and the Islamic community as a symbol of the spread of Islam that has been carried out for many years so that many Indonesian people embrace the Islamic religion.

Currently, Suluk Sunan Bonang is stored neatly at Leiden University Library, Netherlands. Suluk is derived from Arabic, namely salakattariiqa. That is, taking the path (Sufism) or the path. Science is often called the science of seclusion. The usual teaching is delivered with sekar or tembang called suluk. Whereas when expressed in ordinary in the form of prose called wirid. Sunan Bonang died in 1525 . His grave

\section{Sunan Kalijaga}

Sunan Kalijaga has the original name Raden Said. He is the son of Duke of Tuban, Tumenggung Wilatikta. He was born around 1450 AD Raden Said once studied with Sunan Bonang. Raden Said is famous as Sunan Kalijaga. Kalijaga means one who guards the river. Because he had been imprisoned by the river. Method of preaching Sunan Kalijaga; in dakwah, he has the same pattern with the teacher as well as his close friend, Sunan
Bonang. His religious beliefs tend to follow the Sufis. He also uses the arts and culture as a means to facilitate da'wah. Currently the scholars still use the patterns and methods of Kalijaga sunan and the culture of spreading Islam nowadays has been passed down from generation to generation in Indonesia.

Sunan Kalijaga is also very concerned about local culture or local wisdom (local wisdom) which is currently being promoted by the government of President Joko widodo with the priority is the development and formation of pariswisata area. That is, since the first guardian songo had developed the concept of appreciating local wisdom in the surrounding area. Sunan Kalijaga also believes that people will stay away if attacked its establishment. Then they should be approached gradually, following while affecting. Sunan Kalijaga believes that if Islam is understood, by itself the old habits will disappear. There are parties who think that Sunan Kalijaga combines Islamic teachings with other religious teachings (syncretism), Sunan Kalijaga uses carving, wayang, gamelan, and sound art as a voice of dakwah. She made money in celebration of patent, grebeg maulud, Layang Kalimasada, puppet of Petruk Jadi Raja. The central city landscape is a palace, 
the square with two banyan trees and the mosque is believed to be the work of Sunan Kalijaga.

\section{Sunan Kudus}

Sunan Kudus is the original name of Ja'far Sadiq, son of Raden Usman Haji who holds Sunan Ngudung from Jipang Panolan and Syarifah (Sunan Bonang's sister). In addition to teaching his own religion to his father, Raden Ja'far Sadiq also studied with several famous scholars, among them Kiai Ageng Telingsing, Ki Ageng Ngerang, and Sunan Ampel. Kiai Ageng Telingsing's real name is The Ling Sing, he is a scholar from China who came to Java Island with Admiral General Cheng Hoo. Method of Sunan Kudus preaching; Strategy of approach to the masses. Let the old customs and beliefs be difficult to change. The adat section which is not in accordance with the teachings of Islam but easy to change then immediately eliminated. Dakwah methods of the scholars that exist today apply a lot of patterns to change the customs of Indonesian society atheism as well as drinking and party by violating agaa values. So the pattern of Sunan Kudus much adopted by the scholars that exist today in order to dispel kufuran that exist in Indonesian society.

Pattern Method of leadership that is widely applied by the NKRI government especially President Joko Widodo as well as Tut Wuri Handayani has existed since the time of the guardian songo Sunan Kudus, Which means following from behind to the behavior and customs of the people but attempted to influence little by little and apply the principle Tut Wuri Hangiseni. That is, follow from behind while filling the teachings of the existing religion. Islam implements peaceful dissemination without coercion and non-violence in the community. And avoid direct confrontation in broadcasting Islam. In the end may change the customs and beliefs of society that are not in accordance with the teachings of Islam but with the principle does not dispel society from Muslims. This da'wah strategy applied by Sunan Kalijaga, Sunan Bonang, Sunan Muria, Sunan Kudus, and Sunan Gunungjati. Because their strategy in preaching is not the same as the line set by Sunan Ampel then they are called the Abangan or Tuban. Sunan Ampel's opinion, supported by Sunan Giri and Sunan Drajad, is called Putihan or Giri.

Embracing Hindu society; in Kudus at that time many of the inhabitants were Hindus and Buddhists. To invite them to Islam would not be an easy job. Especially those who still embrace the old belief and hold firm to the 
old customs, the amount is not small. It was in such a society that Ja'far Shadiq had to fight for religion. One day Sunan Kudus or Raden Ja'far Sadiq bought a cow (in another narration called Kebo Gumarang). The cow is from India. The cow is moored in the yard of Sunan Kudus. The Hindu people, mostly Hindus, were moved, wondering what Sunan Kudus would do to the cow. The cow in view of Hinduism is the sacred animal that becomes the vehicle of the gods. Cow slaughter is a sin committed by the gods. Then what will Sunan Kudus do? After the growing number of people, Sunan Kudus came out of his house and said, "Sedulursedulur that I respect, all my relatives sometimes I love, I forbid brothers hurt let alone slaughter cows. Because when I was little, I had a dangerous time, almost died of thirst and a cow came to feed me."

Hearing the cheerful, the Hindus admires. They thought Raden Ja'far Sadiq was the incarnation of Lord Vishnu, so they were willing to listen to his lecture. The community is increasingly interested, when hearing a lecture from Sunan Kudus that in the Qur'an there is a surah Al Baqarah which means cow. They want to know more and for that they must often come to hear the Sunan Kudus. The form of a mosque made by Sunan
Kudus was not much different from Hindu temples. Thus, after the sympathy was successfully obtained will field the way to invite people flock to convert to Islam.

Embracing Buddhist society; After the mosque stands, Sunan Kudus makes a pad or wudlu place with a shower that amounts to eight. Each shower is statued with Kebo Gumarang head on it. This is adapted to the Buddhist teachings of "Eightfold Path" or "Asta Sanghika Marga" that is: (1) having correct knowledge, (2) making correct decisions. (3) Says right. (4) live the right way. (5) works correctly. (6) worship properly. (7) live the religion correctly. With this effort, many Buddhists are curious, for what Sunan Kudus put a symbol of the Buddha's will in the padasan. So they came to the mosque to listen to the Sunan Kudus. Selamatan mitoni; as is known, many Javanese people who do strange customs, which contrary to the teachings of Islam, such as sending offerings in the cemetery to show condolences or grieving over the death of one family member, selamatan neloni, mitoni, and others. Sunan Kudus is very concerned about the ritual ceremonies, and try his best to change or direct it in the form of Islami. This is done also by Sunan Kalijaga and Sunan Muria. 


\section{Sunan Drajad}

Sunan Drajad has Raden Qasim's real name, son of Sunan Ampel with Dewi Condrowati and is the sister of Raden Makdum Ibrahim or Sunan Bonang. Raden Qasim was ordered by his father to preach in the west of Gresik, the empty area of the great scholars between Tuban and Gresik. Then Raden Qasim built a strategic dakwah place on Dalem Duwur hill, which is now built the Sunan Drajad museum, while the tomb of Sunan Drajad lies to the west of the museum.

Method of propagation of Sunan Drajad; Raden Qasim is a white-backed supporter led by Sunan Giri. That is, in preaching propagate the religion of Islam, he embraced a straight path, a path that is not tortuous. Religion must be practiced straight and true according to the teachings of the Prophet. Must not be mixed with old customs and keperceyaan. Even so, he also uses folk art as a tool of propaganda. The famous Sunan Drajad teachings are: (1) Al qur'an (2) Sunnah (3) Ijma '(4) Qiyas (5) teachings of teachers and educators such as Sunan Ampel or his parents (6) teachings and thoughts or (7) Traditions in existing local communities that are in accordance with Islamic teachings (8) Sunan Drajad's own fatwa.

\section{Sunan Muria}

Sunan Muria has the real name of Raden Umar Said. He is the son of Sunan Kalijaga with Dewi Saroh. In da'wah, he uses a subtle way. His residence on Mount Muria is one of its peaks named Colo. It is located north of Holy City. His targets of preaching are traders, fishermen, sailors, and commoners. He is the only guardian who retains the art of gamelan and wayang as a propagation tool to convey Islam.

\section{Sunan Gunungjati}

Sunan Gunungjati has the original name Syarif Hidayatullah. $\mathrm{He}$ is the son of the great Egyptian descendants of Bani Hashim from Palestine, Sultan Sharif Abdullah Maulana Huda with Syarifah HidayatMudaim, a princess of the king of Pajajaran. Syarif Hidayatullah continue the efforts of Sheikh Datuk Kahfi open Pesantren Gunungjati. So Syarif Hidayatullah better known as Sunan Gunungjati.

In spreading Islam in Java, he does not work alone, he often participates in deliberation with other members of the guardian at Demak Mosque. Even he also helped the founding of Demak Mosque. In da'wah, Sunan Gunungjati embraces a plain Middle East tendency. But he also approached the people by building infrastructure in the form of roads that connect between regions. 
Syarif Hidayatullah studied religion since the age of 14 years from the scholars of Egypt. He had traveled to various countries. Following the establishment of the Sultanate of Bintoro Demak, and on the blessing of other scholars, he established the Sultanate of Cirebon, also known as the Pakungwati Sultanate. Thus Sunan Gunungjati is the leader of the government.

\section{CONCLUSION}

From the research found several conclusions of several points, namely: First; For Muslims, religion and nationalism do not conflict with the government of the Republic of Indonesia On the contrary, Islam teaches love to the homeland and submission to the government as long as he does not deviate from the Islamic Shari'a. The role of walisongo first appeared, starting from the island of Java. Wali songo is the spreader of Islam in Indonesia which makes many changes for Muslims in Indonesia that also strengthen the government of NKRI. In the spread of the religion of Islam, many challenges and obstacles are experienced for the upholding of true religion and in accordance with the shari'ah of Islam. Especially in carrying out the da'wah, many walisonga using traditional tools that already exist in the existing area dimedan to preach. With patience and persistence possessed by the walisongo, able to teach and convince the knowledge of ketauhidan to Allah SWT. The success of Islamization of Java is the result of walisongo struggle and hard work that became the basic foundation of the spread of Islam by the scholars that exist today and strengthen the government of NKRI President Joko Widodo. The process of Islamization is largely peaceful, almost without conflict, political or cultural. Although there are conflicts at once the scale is very small, so it is not as impressive as war, violence or cultural coercion, so the population of Java embraces Islam voluntarily.

Secondly, the Organization of Islamic Communities (Persons), namely Persis, Ikatan Jamaah Ahulul Bait Indonesia (IJABI) and Mathaul Anwar are the three major Islamic organizations that strengthen the government of NKRI. Where is the Persatuan Islam (Persis) known as the puritan movement, as well as the Ikatan Jamaah Ahulul Bait Indonesia (IJABI) which is a Shia representation and therefore becomes part of the trans national movement; Making the NKRI as a joint political building that in strengthening and strengthening the existence of NKRI.

\section{SUGGESTION}

After we know briefly about the role of scholars in the Government of the Republic of Indonesia or in the method of Islamic da'wah in Indonesia, especially in Java. The author understands in this writing will be an important role of 
scholars who have struggled for the process of Islamization kususnya in this Java. And do not forget also the writers always pray the previous scholars for the progress and prosperity of Indonesia My homeland and really can provide coolness for the life of the people of Indonesia and the existence of Ulama and Muslims in Indonesia is within the framework of strengthening the Government in the Era of Government President Joko Widodo ${ }^{10}$.

\section{BIBLIOGRAPHY}

Ahmadi, Rulam. 2005. Understanding Qualitative Research Methodology. Surabaya: UNM Publisher.

Ali Shodiqin (2009), Anthropology of the Qur'an, Yogyakarta: arRuz Media

Al-Maraghi, Ahmad Mustofa (1992), Tafsir al-Maraghi, terj, Bahrun Abu Bakar et al. Semarang: The work of Toha Putra

Arkoun, Mohammed. 1994. Reason of Islam and Modern Reason: Challenges and New Paths. Jakarta: INIS.

Azyumardi Azra, et al. (2008), Thematic Review of the

${ }^{10}$ The attitude of President Joko Widodo who is willing to meet the National Movement of Fatwa Guards of the Indonesian Ulema Council, or GNPF-MUI in the Eid alFitr moment, reap the appreciation. It is hoped that this meeting will bring about government policy, as well as apparatus that can be fair to the ulama, so as to create a conducive atmosphere http://www.viva.co.id/berita/politik/930476-jumpajokowi-gnpf-expected-accommodate- For-scholars
Qur'an about Society, Bandung: Space

Bogdan, Robert and Steven J. Taylor. 1975. Introduction to Qualitative Research Methods:

Phenomenological Approach to the Social Science. New York, Willey.

Brown, Donald. "Poverty-Growth Dichotomy". Under Kirdar and Leonard Silk (eds.), People: From Impoverishment to Empowerment. New York: New York University Press, 1995.

Badri Yatim, History of Islamic Civilization (Jakarta: PT.Raja Grafindo Persada, 2007)

http://jainestalugo.blogspot.co.id/201 4.

Brunessen Martin van, 1998. Small People, Islam, and Politics. Yogyakarta: Yayasan Bentang Budaya

Dhofier, Zamakhsyari. 1982. The

Tradition of Pesantren: Studies on the Kyai Life View. Jakarta: LP3ES.

Dirdjosanjoto. Pradjarta 1999. Maintaining People: Kyai Pesantren-Kyai Langgar in Java. Yogyakarta: LKIS.

Effendi, Bahtiar. 1998. Islam and the

State: Transformation of Islamic Political Thought and Practice in Indonesia. Jakarta: Paramadina. 
Ellen, Roy. 1982. Environment, Subsistence and System. Cambridge University Press.

Faridl, Miftah. 2000. The Role of the Theological Perception in Social Political Behavior of Kyai. (Dissertation at IAIN Syarif Hidayatullah Jakarta).

Feith Herbert. 1999. General Election 1955. Jakarta: Popular Gramedia Library (KPG).

Francis Wahono Nitiprawiro (2008), Liberation Theology, Yogyakarta: LkiS.

Freed, Stanley A. \& Freed, Ruth S. 1977. Anthropology and the Climate of Opinion / Annals of the New York Academy of Sciences Vol 293, in Prasetijo. WordPress.

Freire, Paulo. 1985. Education of the Persecuted. Jakarta: LP3ES.

Friedman, John. 1988. Planning As A Learning Process in Korten and Sjahrir (editors). Development of Peopledimensionality. Jakarta: Yayasan Obor Indonesia.

Friedman, John.

1992.

Empowerment: The Politics of Alternative Development. Cambridge: Blackwell.

Garna, Judistira K. 1996. Social Sciences; Basic-ConceptPosition. Bandung:

Postgraduate UNPAD.

Garna, Judistira K. 2002. Theories of Social Change. Bandung: The Judistira Foundation and Primaco Akademika
Garna, Judistira K. 2009. Research Method: Qualitative (Issue III). . Bandung:

Geertz, Clifford. 1960, "The Javanese Kijaji: The Changing Role of a Cultural Broker", Comparative Studies in Society and History, (1959-1960), Vol 2

Geertz, Clifford. 1981. Abangan, Santri, Proyayi in Javanese Society (Translation by Aswab Mahasin). Jakarta: Pustaka Jaya.

Gelnerr, Ernest. 1997. Culture, Identituy and Politic. Cambridge: Cambridge University Press.

Gillin, John Lewis, and Gillin, John Philip. 1954. Cultural Sociology. The Macmilillan Company. New York. USA.

Greg Feally and Greg Barton. 1997. Radical Traditionalism: The Nahdlatul Ulama-Negara Relation. Yogyakarta: LKIS. Gufroni, Mohammed. 2010. Kiai Anthropolgi: Kiai as a Political and Cultural Bridge. Blogger.

Gustav Ranis, 1977. Trade Off or Complements (in Economic Development Poverty and Economic Distribution).

Haedar, Ruslan A. 2009. Dynamics of Leadership Dynamics Kiyai In Pesantren. Wacanaislam. Blogspot.com. Hanna, M.G. And Robinson, B. 1994. Strategies for Community Empowerment: 
Direct Action and Trasformative Approaches in Social Change Practice. New York: The Edwin Mellen Press.

Hardesty, Donal, L. 1977. Ecological Anthropology. New York: John Wiley and Sons.

Wisdom, Harry. 2003. Marginalization of Local Communities in Perspective of Contingency of Community Empowerment Strategy (Case Study in Bekasi City). Dissertation: UNPAD Graduate Program. Bandung.

Horikoshi, Hiroko 1987. Kyai and Social Change. Jakarta: P3M. Ibn Hajar (2009), Kiai in the Middle of the Political Strands, Yogyakartal: Ircisod

Kartasasmita, Ginanjar. 1997.

Community Empowerment:

The Concept of CommunityRooted Development. Jakarta: Bappenas.

Kearl, Brian E., 1995. Communications for Agricultural Development in the Role of Mass
Communications in Development (Edward Depari and Collin Mc Andrews Editors, Gajah Mada University Press, Jogjakarta.

Khun, Thomas S. 1993. The Role of Paradigms in the Science Revolution. Jakarta: Teens Rosda Karya.

Koentjaraningrat. 1985 and Harsojo. 2002. Sundanese Culture: Human and Culture in Indonesia. 19th Print. Publisher Djambatan, Jakarta. Koentjaraningrat. 1985. Culture of Mentality and Development in Indonesia. 19th Print. Publisher Djambatan, Jakarta.

Koentjaraningrat. 1985. History of Theory of Anthropology II. Jakarta: UI Press.

Kristiadi. J. 2004. Politics Post 2004 Election and Political Transition In Indonesia. Jakarta: State Administration Institution.

Kustiani. Santi 2005. The Impact of Kliwonan Market Tradition on Community Empowerment Efforts. Semarang: UNES. 